JSIP: Jurnal Studi Ilmu Pemerintahan

Volume 3, No 1 Februari 2022

ISSN: 2722-7405

\title{
PENGARUH SOSIAL MEDIA TERHADAP PERSEPSI PUBLIK DALAM PEMILIHAN KEPALA DAERAH DI SUMBAWA TAHUN 2020
}

\author{
Irawansyah ${ }^{1}$, Supriadi ${ }^{2}$, Kikis Kayasi ${ }^{3}$ \\ 1,2,3Program Studi Ilmu Pemerintahan, Institut Ilmu Sosial dan Ilmu Budaya Samawa Rea, Indonesia \\ Email: irawansyahparera13@gmail.com
}

\section{Article Info}

\section{Keyword:}

Social Media ${ }^{1}$, Public

Perception², Pilkada ${ }^{3}$.

Kata Kunci:

Media Sosial ${ }^{1}$, Persepsi

Publik', Pilkada ${ }^{3}$.

\begin{abstract}
The purpose of this study was to determine the impact of social media on public perception of regional head elections in Sumbawa in 2020. The method used was a qualitative method with a descriptive approach, data collection techniques with interviews, documentation, and literature studies related to the problems studied. The results of this study indicate that social media can influence public perception in the election by becoming a political campaign and marketing tool, namely the first 4 Ps are products; The most important product of a political party is of course the candidate himself along with the party platform, concept, and work program of the political party itself. Second promotion: A good promotion is not luck, but a good promotion must be placed precisely where the sale will take place, how the promotion will run and for whom the promotion is. Third price: Price or price in political marketing includes several things ranging from economic, psychological image to national image. Fourth place: places related to pairs of candidates can maximize all potential voters well or effectively, political socialization to pairs of candidates can accommodate all levels of society. Candidate pairs are always able to classify, map, and analyze layers and forms of community characteristics.
\end{abstract}

Abstrak: Tujuan dari penelitian ini adalah untuk mengetahui dampak media sosial terhadap persepsi publik terhadap pemilihan kepala daerah di Sumbawa tahun 2020. Metode yang digunakan adalah metode kualitatif dengan pendekatan deskriptif, teknik pengumpulan data dengan wawancara, dokumentasi, dan studi pustaka yang berkaitan dengan permasalahan yang diteliti. Hasil penelitian ini menunjukkan bahwa media sosial dapat mempengaruhi persepsi publik dalam pilkada dengan menjadi alat kampanye dan marketing politik, yaitu $4 P$ yang pertama produk; produk terpenting dari partai politik tentunya kandidat itu sendiri bersama platform partai, konsep dan program kerja dari partai politik itu sendiri. Kedua promotion: Promosi yang baik bukanlah keberuntungan, tetapi promosi yang baik harus ditempatkan dengan tepat dimana penjualan akan berlangsung, bagaimana jalannya promosi dan untuk siapa promosi itu. Ketiga price: Price atau harga dalam pemasaran politik mencakup beberapa hal mulai dari ekonomis,citra psikologi hingga citra nasional. Keempat place: tempat berkaitan dengan pasangan calon dapat memaksimalkan semua calon pemilih secara baik ataupun efektif,sosialisasi politik pada pasangan calon dapat mengakomodir semua lapisan masyarakat. Pasangan calon senantiasa mampu mengelompokkan, memetakkan, serta menganalisis lapisan dan bentuk karakteristik masyarakat. 


\section{PENGANTAR}

Internet suatu hal yang yang tidak dapat dipisahkan lagi bagi kehidupan masyarakat, baik diwilayah perkotaan atau pedesaan.Seiring dengan berkembangnya teknologi informasi komunikasi yang semakin pesat, internet telah masuk dan merambah secara pesat dalam kehidupan manusia (Allcott \& Gentzkow, 2017). Hal ini menuntut masyarakat untuk memanfaatkan kemajuan teknologi dalam berkomuinikasi.Karena komunikasi merupakan kegiatan timbal balik antara pemberi informasi atau Informan dengan Publik atau masyarakat, dengan kemajuan teknologi membuat komunikasi saat ini sangat mudah dilakukan dimana saja dan kapan saja, khususnya melalui media sosial.

Maraknya perkembangan media sosial ini dapat dimanfaatkan oleh Informan untuk kepentingan tertentu, misalnya promosi barang, perbaikan citra sesorang atau hal lain (Enli, 2017). Kehadiran media sosial sendiri mempengaruhi bidang politik, riset ilmiah tentang pemanfaatan media sosial dalam Pemilihan Kepala Daerah menarik untuk dilakukan, melihat kemajuan teknologi di dalam politik sekarang sudah banyak sekali membawa manfaat khususnya media sosial. Adanya pandemi corona saat ini membuat media sosial sangat terlihat berguna dalam politik. Media sosial sendiri lazim digunakan oleh para pasangan politik untuk mempublikasikan aktivitasnya, visi dan misi, termasuk pemasaran dan kontribusi yang akan dilakukan dalam memajukan daerah (Cameron et al., 2016). Hal ini dilakukan untuk menarik perhatian masyarakat dengan jangkauan yang lebih luas tanpa adanya tatap muka dengan masyarakat, masyarakat sudah dapat melihat gambarannya melalui media sosial.

Studi Amerika menunjukkan media sosial sebagai alat komunikasi yang efektif, tidak dapat dipungkiri bahwa dalam kurun waktu yang singkat dan sangat cepat setiap masyarakat akan mudah menguasai bagaimana cara menggunakan sosial media yang sudah ada,maka para masyarakat akan lebih mudah mendapatkan pesan dan mengeluarkan opini masing masing (Fulgoni et al., 2016). Setiap individu memiliki persepsi atau pendapat masing-masing mengenai pesan yang disampaikan komunikator, tapi tidak semua masyarakat ikut memberikan pendapat di kolom komentar, ada yang akan membahas hal yag sama ketika mereka mempunyai waktu senggang, dan sebaliknya ada yang hanya membaca dan tidak meninggalkan komentar. Melihat banyaknya masyarakat tentu tidak semua pendapat masyarakat sejalan dan berisi hal positif melainkan ada juga pendapat negatif hal ini adalah hal yang tetap ada dalam bersosial media karena pandangan dan persepsi masyarakat itu berbeda beda antara yang satu dengan yang lainnya.

Persepsi adalah proses seseorang menjadi sadar akan segala sesuatu dalam lingkungannya melalui indra yang dimilikinya atau pengetahuan lingkungan yang diperoleh melalui interpretasi data indra (Williams, 2017). Persepsi ini bisa menjadi bentuk pemikiran masyarakat setelah memilah suatu hal terkait.

Persepsi ataupun opini masyarakat atau masyarakat dapat dibentuk dengan adanya sedikit pencitraan di dari isi pesan yang akan disampaikan Informan kepada masyarakat, maka dari itu Informan harus melihat, mengatur dan teliti dengan pesan yang akan di sebarluaskan, pesan harus dikemas dengan sangat baik sehingga dapat dicerna dengan baik oleh masyarakat yang menjadi sasaran informan atau para kandidat politik sehingga antara media sosial dan persepsi publik berjalan secara beriringan (Harder et al., 2017). Opini publik juga dapat dipengaruhi oleh diskusi antara masyarakat dan komunikator, opini yang tercipta tergantung bagaimana Informanmenyampaikan pesannya kepada sasaran.

Media sosial seperti yang kita ketahui mampu menjangkau Masyarakat seluas luasnya hal ini membuat masyarakat yang ada di pelosok sekalipun bisa tau apa saja perkembangan dari masing masing Pasangan Calon dengan hanya melihat sosial media mereka (Chauhan et al., 2021; Sinpeng et al., 2020), hal ini akan sangat membantu masyarakat dalam mengenali apa saja tentang para kandidat tanpa bertemu secara langsung, dari sini masyarakat bisa membuat penilaian mengenai masing masing pasangan politik yang mengikuti Pemilihan Kepala Daerah tahun 2020.

Pemilihan Kepala Daerah dilakukan satu paket bersama wakil Kepala Daerah. Kepala Daerah dan wakil Kepala Daerah yang dimaksud mencakup Gubernur dan wakil Gubernur untuk 
provinsi, Bupati dan wakil bupati untuk kabupaten,dan Walikota dan wakil Walikota untuk kota. Pemilihan Kepala Daerah diselenggarakan oleh Komisi Pemilihan umum atau KPU Kabupaten atau kota dengan diawasi oleh Badan Pengawas Pemilihan UmumProvinsi dan bawaslu Kabupaten. Berdasarkan Undang- undang nomor 32 tahun 2004 peserta pemilihan Kepala Daerah adalah pasangan calon yang diusulkan oleh partai politik atau gabungan partai politik. KPU Kabupaten Sumbawa menetapkan ada lima pasangan politik yang maju mencalonkan diri pada Pemilihan Kepala Daerah tahun 2020 lalu,penetapan ini dilakukan berdasarkan hasil rapat pleno internal KPU Sumbawa.

\section{METODE PENELITIAN}

Dalam penelitian ini peneliti menggunakan pendekatan kualitatif. Metode kualitatif merupakan penelitian yang dapat atau mampu menghasilkan data deskriptif yang berupa katakata, lisan, ataupun tulisan dengan perilaku yang dapat diamati dari orang yang akan diteliti.Karena berbicara tentang pengaruh media sosial terhadap persepsi masyarakat dalam kontestasi pemilihan umum atau pemilihan kepala daerah dibutuhkan data yang lebih deskriptif berupa tulisan dari lisan atau dari data primer dan skunder yang kemudian di deskrIptifkan. penelitian kualitatif adalah penelitian yang bermaksud untuk memahami fenomena tentang apa yang di alami oleh subjek penelitian minsalnya prilaku, persepsi, motivasi, tindakan dan lain-lain secara holistik dan dengan cara deskripsi dalam bentuk kata-kata dan bahasa, pada suatu konteks khusus yang alamiah dan dengan memanfaatkan berbagai metode alamiah.

Alasan penulis memilih pendekatan ini sebagai acuan analisis karena pendekatan ini di anggap sesuai dalam analisis permasalahan penelitian yang akan diteliti. Dalam penelitian ini juga berusaha memahami objek penelitian sesuai dengan fakta yang ada dilapangan tanpa adanya rekayasa/memanipulasi data, dalam hal ini peneliti mampu memahami semua fenomena yang ada baik dalam segi prilaku, maupun motivasi dan kemudian dituangkan kedalam bentuk kata ataupun kalimat yang nantinya bisa dipahami.

\section{HASIL DAN DISKUSI}

Pengaruh Media Sosial terhadap persepsi publik dalam Pemilihan Kepala Daerah di Kabupaten Sumbawa Tahun 2020. Media Sosial di era sekarang membawa dampak buruk dan dampak baik bagi pertumbuhan bangsa dan negara, media sosial secara mendasar membuat orang saling terhubung satu sama lain, di era sekarang media sosial pun dimanfaatkan untuk tujuan yang lebih luas lagi (Budiyono, 2016), sebab media sosial bisa di intrepretasikan sebagai kebutuhan mendasar ummat manusia, apalagi di era pandemi ini yang melanda hampir di seluruh belahan dunia membuat ruang gerak, ruang interaksi manusia satu dengan yang lain semakin berjarak.

Media sosial pun dapat menjadi solusi satu-satunya untuk bisa saling terhubung satu dengan lain untuk waktu yang cepat dan bisa terhubung ke seluruh dunia, di era pandemi ini segala sesuatu serba online, mulai kebutuhan pendidikan, ekonomi, politik, dan sosial budaya bisa diakses melalui media online dan media sosial pun menjadi salah satu media online yang memberi fasilitas untuk kebutuhan tersebut. Pemilihan Kepala Daerah di Kabupaten Sumbawa pun juga memanfaatkan media sosial sebagai sarana informasi, sosialisai, kampanye bahkan sampai pada pembangunan opini politik yeng mempengaruhi masyarakat sebagai strategi politik dalam meraih simpati masyarakat.

Media Sosial Sebagai Media Informasi Publik dalam menyampaikan Informasi Politik. Media Soisal juga dimanfaatkan sebagai salah satu media online untuk tempat menyampaiakan segala bentuk Informasi, mulai dari pendidikan, ekonomi, politik dan sosial budaya (Efriza, 2019), dalam proses Pemilihan Kepala Daerah di Kabupaten Sumbawa di era pandemi ini sungguh sangat berat bagi pemerintah atau instansi pemerintahan menyampaikan informasi dengan cepat dan marata, media sosial pun sering dimanfaatkan untuk hal yang demikian, pilihan media sosial pun beragam seperti, whatsaap, facebook, instagram dan twitter.

Adapun yang disampaikan oleh Admin sebuah akun media sosial yang cukup besar di Sumbawa yaitu akun Semaras Sia yang didalamnya tergabung banyak masyarakat dalam maupun luar daerah Sumbawa,akun ini dibuat untuk membagikan segala kegiatan yang harus di ketahui oleh masyarakat,termasuk tentang Pilkada tahun 2020 kemarin,yang bersangkutan mengatakan: 
"Bahwa media sosial ini sangat sangat berpengaruh terhadap jalannya pemilihan kepala daerah,beliau mengatakan media sosial ini pengaruhnya sangat signifikan lantaran didalam akun ini saja dapat mempengaruhi beribu ribu orang,tapi beliau menyebutkan bahwa salah satu konsekuensi nya adalah kita harus berusaha bersikap netral di depan netizen,karena kalau tidak admin juga akan diserang oleh yang pro dan kontra. Pada akhirnya admin sendiri pro kepada salah satu pasangan calon secara priadi,tidak dengan mempublik secara luas tentang pasangan ini secara spesial,hanya dengan mengerahkan tiga puluh persen peran media saja mampu mengantongi suara sebanyak ini apalagi jika kekuatannya di kerahkan maksimal sampai seratus persen,mungkin yang terpilih menjadi Bupati sekarang akan berbeda karena pada akhirnya Admin sendiri pro kepada salah satu pasangan calon".

Kenapa hanya tiga puluh persen yang dikerahkan,karena pasangan calon itu sendiri tidak mau terlibat secara langsug dengan admin,tidak melakukan pendekatan secara pribadi,hal ini sangat disayangkan karena nanti apabila pasangan ini terpilih maka media sosial ini juga ikut andil dalam pemenangan tersebut. Sehingga pada akhirnya media ini hanya mengerahkan kekuatan sebanyak tiga puluh persen saja. Hal itu membuktikan bahwa mengantongi suara satu orang saja bisa mendapatkan ribuan suara hanya melalui permainan sosial media.

Dalam hal ini pemanfaatan media sosial sebagai salah satu media online juga dimanfaatkan sebagai media kampanye para pasangan calon kepala daerah di Kabupaten Sumbawa pada tahun 2020, dengan pemanfaatan yaitu, membangun opini publik sehingga masyarakat mempunyai persepsi terseendiri bagi seluruh pasangan calon Bupati dan Wakil Bupati Kabupaten Sumbawa yang bakal menjadi pemimpin baru di Kabupaten Sumbawa, dibuktikan dengan hasil wawancara dengan salah satu masyarakat Kelurahan Barang Biji, Kecamatan Sumbawa, beliau mengatakan :

"Saya juga sering terlibat debat di grup facebook pada saat Pemilihan kepala Daerah di Kabupaten Sumbawa pada tahun 2020" (Hasil Wawancara, 29 Juli 2021).

Berdasarkan wawancara di atas menjelaskan bahwa penggunaan media sosial dapat menggiring persepsi masyarakat dalam hal memilih dan memilah calon pasangan Bupati dan Wakil Bupati Kabupaten Sumbawa tahun 2020, dengan demikian sebenrnya sederhana saja, persepsi secara mendasar sangat mudah sekali dibuat dan mudah sekali menjamur didalam otak masyarakat, dengan pembangunan opini yang matang tentunya membawa syarat terbangunnya persepsi itu sendiri, tetapi yang jadi persoalan seberapa kuat opini yang dibangun itu dapat mempengaruhi masyarakat, sehingga dapat menimbulkan persepsi yang sesuai dengan keinginan individu atau kelompok pembuat opini, disinalah peran konsultan politik yang pastinya sangat bertanggung jawab mengenai strategi pemenangan masing-masing pasangan calon Bupati dan wakil Bupati Kabupaten Sumbawa tahun 2021, tetapi yang jelas segala berita yang dimuat dimedia sosial kemudian dikonsumsi secra terus-menerus oleh masyrakat, pastinya dapat mebangun persepsi di masyarakat. Proses pemasaran politik berbeda dengan proses pemasaran komersial, ketidak samaan pada hal-hal yang menjadi pembahasa pada semua tahap proses politik marketing dan komersial marketing (Sa'ban et al., 2021). Proses pemasaran, Niffenneger berpendapat, memiliki empat bauran pemasaran.

Dibawah ini merupakan $4 \mathrm{p}$ pada pola marketing politiknya Niffenneger:

\section{Product}

Niffengger member dua pandangan yakni platform partai dan masa lalu kandidat. Platform atau paradigma partai yang mengandung konsep, identitas ideologis, dan program kerja dari partai politik ini tentunya adalah produk utama dari partai politik (Anggraeni \& Adrinoviarini, 2020). Dalam hal ini, perlu melihat platform pendukung, rekam jejak calon, dan karakteristik platform.

\section{Promotion}

Dalam pemasaran politik, promosi harus digunakan sebagai alat untuk "menjual" produk politik, seperti calon. Baik promosi bukanlah keberuntungan, promosi baik harus menempatkan dengan tepat dimana penjualan akan berjalan, bentuk jalannya promosi, dan kepada siapa promosi itu dilakukkan (Cameron et al., 2016). Dalam marketing politik, promosi adalah suatu hal yangharus digunakan. Dalam hal ini, bagaimana tim pemasaran calon menentukan sukses tidaknya suatu promosi dijadikan alat untuk "menjual" produk 
politik, seperti calon. Dalam promosi calon, penting untuk mengetahui jargon apa yang digunakan, media yang mau bekerja sama dengan mereka, dan artis seperti apa yang digunakan

3. Price

Price dalam politik pemasaran mengacu pada berbagai faktor, mulai dari ekonomi, psikologi, hingga identititas Kebangsaan Niffenegger (Sophia \& Noviwinarti, 2019). Citra psikologis berdasarkan persepsi psikologis yang dimilih, seolah-olah pemilih merasa nyaman dengan pasangan calon tersebut, harga ekonomi adalah banyak dana kampanye yang dikeluarkan selama periode kampanye.

\section{Place}

Place atau lokasi yang berkaitan dengan bagaimana seorang calon dapat secara efisien mengelola semua orang yang menjadi tanggung jawabnya. Kampanye atau sosialisasi politik kepada pasangan calon harus mampu menjangkau semua lapisan/kalangan masyarakat (Darmoko \& Ratnaningtyas, 2017). Pasangan calon harus mampu mengelompokan, memetakan, serta menganalisa struktur dan karakter masyarakat. Pendalaman dilaksanakan dengan cara mengamati konsentrasi penduduk di suatu tempat atau wilayah, penyebarannya dan kondisi fisik geografisnya. Pemetaan perlu dilakukan melalui pengamatan demografi, di mana pemilih dikelompokkan berdasarkan tingkat stratifikasi pendidikan, pekerjaan, usia, kelas social dan pemahaman tentang keyakinan politik, agama dan etnis. Pemetaan juga perlu di dasarkan pada keberpihakan pemilih, seperti jumlah pendukung dari partai politik, berapa jumlah pendukung dari kandidat lain, seberapa jumlah pemilih atau masa yang mengambang, dan berapa persentase golput.

\section{KESIMPULAN}

Berdasarkan penelitian dan hasil analisis bisa ditarik kesimpulan bahwa dengan penggunaan media sosial sebagai media marketing politik yang sangat berpengaruh terhadap persepsi publik dalam pemilihan kepala daerah di Sumbawa Besar tahun 2020, menunjukkan bahwa media sosial sebagai media informasi politik, adanya media sosial adalah suatu keringanan dalam penyebaran informasi mengenai berbagai hal termasuk tentang politik masa kini,media sosial menjadi media yang sangat uptodate jaman sekarang karena media sosial memiliki ruang yang tidak terbatas,kapanpun dan dimanapun. Informasi tentang politik sangat intens terdapat di media sosial,dibuktikan dengan apapun hal yang kita ingin ketahui seputaran pasangan calon dapat kita temui di dalam media sosial. Media sosial sebagai alat komunikasi politik, Ini dibuktikan dari adanya postingan yang bersangkutan dengan hal hal yang menyangkut pasangan calon politik,hal ini dilakukan semata mata mencoba untuk berkomunikasi dengan masyarakat melalui media sosial. Adanya hal tersebut maka masyarakat akan melakukan timbal balik dengan cara mengisi di kolom komentar dengan berbagai macam pesan dukungan ataupun sebaliknya.

Media sosial sebagai media campanye,media sosial adalah salah satu strategi yang paling fleksibel dan efektif digunakan,dibandingkan spanduk dan baliho. Orang yang relative terdidik dan well inform ini tidak akan percaya isi baliho atau spanduk,tapi lebih percaya pada perkataan teman atau koleganya di media sosial. Disini dapat dikatakan bahwa setiap orang dapat berpengaruh bagi orang lain. Penyebaran berbagai ide,termasuk isi kampanye via media sosial berlangsung amat cepat dan hampir tanpa batas. Media sosial berperan besar membentuk persepsi masyarakat(publik) dalam Pilkada di Sumbawa Besar tahun 2020. Adanya postingan calon pasangan politik di media sosial mampu menimbulkan persepsi masyarakat berbeda beda dapat dilihat dari komentar-komentar masyarakat yang mengandung pro dan kontra,adanya pro dan kontra menunjukkan bahwa setiap masyarakat tidak menerima pesan yang disampaikan melalui media sosial ini secara sama. Ketika masyarakat menerima,meresapi,dan memahami isi pesan secara berbeda maka otomatis persepsi yang timbul juga akan berbeda.

\section{REFERENSI}

Allcott, H., \& Gentzkow, M. (2017). Social media and fake news in the 2016 election. Journal of 
Economic Perspectives, 31(2), 211-236. https://doi.org/10.1257/jep.31.2.211

Anggraeni, D., \& Adrinoviarini, A. (2020). Strategi Pengawasan Terhadap Ujaran Kebencian Di Media Sosial Pada Pemilu. AL WASATH Jurnal Ilmu Hukum, 1(2), 99-116. https://doi.org/10.47776/alwasath.v1i2.60

Budiyono, M. (2016). Media Sosial Dan Komunikasi Politik: Media Sosial Sebagai Komunikasi Politik Menjelang Pilkada Dki Jakarta 2017. Jurnal Komunikasi, 11(1), 47-62. https://doi.org/10.20885/komunikasi.vol11.iss1.art4

Cameron, M. P., Barrett, P., \& Stewardson, B. (2016). Can Social Media Predict Election Results? Evidence From New Zealand. Journal of Political Marketing, 15(4), 416-432. https://doi.org/10.1080/15377857.2014.959690

Chauhan, P., Sharma, N., \& Sikka, G. (2021). The emergence of social media data and sentiment analysis in election prediction. Journal of Ambient Intelligence and Humanized Computing, 12(2), 2601-2627. https://doi.org/10.1007/s12652-020-02423-y

Darmoko, H., \& Ratnaningtyas, D. (2017). Audit dana kampanye Pemilihan Umum Kepala Daerah menurut persepsi partai politik, Komisi Pemilihan Umum Daerah, dan auditor kantor akuntan .... In Jurnal Ekomaks.

Efriza, N. (2019). Eksistensi Partai Politik Dalam Persepsi Publik [The Existence of The Political Parties in Public Perception]. Jurnal Politica Dinamika Masalah Politik Dalam Negeri Dan Hubungan Internasional, 10(1), 17-38. https://doi.org/10.22212/jp.v10i1.1314

Enli, G. (2017). Twitter as arena for the authentic outsider: exploring the social media campaigns of Trump and Clinton in the 2016 US presidential election. European Journal of Communication, 32(1), 50-61. https://doi.org/10.1177/0267323116682802

Fulgoni, G. M., Lipsman, A., \& Davidsen, C. (2016). The power of political advertising: Lessons for practitioners: How data analytics, social media, and creative strategies shape U.S. presidential election campaigns. Journal of Advertising Research, 56(3), 239-244. https://doi.org/10.2501/JAR-2016-034

Harder, R. A., Sevenans, J., \& Van Aelst, P. (2017). Intermedia Agenda Setting in the Social Media Age: How Traditional Players Dominate the News Agenda in Election Times. International Journal of Press/Politics, 22(3), 275-293. https://doi.org/10.1177/1940161217704969

Sa'ban, L. . A., Nastia, N., Wijaya, A. A. M., \& Lawelai, H. (2021). Mengawal Pemilihan Legilatif Tahun 2019 Di Kota Baubau. Jurnal Ilmiah Muqoddimah: Jurnal Ilmu Sosial, Politik Dan Hummanioramaniora, 5(1), 226. https://doi.org/10.31604/jim.v5i1.2021.226-234

Sinpeng, A., Gueorguiev, D., \& Arugay, A. A. (2020). Strong fans, weak campaigns: Social media and duterte in the 2016 philippine election. Journal of East Asian Studies, 20(3), 353-374. https://doi.org/10.1017/jea.2020.11

Sophia, U., \& Noviwinarti, N. (2019). Pemetaan Media Massa Dan Media Sosial Sebagai Saluran Komunikasi Politik Pada Pilkada Kota Tanjungpinang 2018. Jurnal Riset Komunikasi, 2(2), 184-201. https://doi.org/10.24329/jurkom.v2i2.66

Williams, C. B. (2017). Introduction: Social media, political marketing and the 2016 U.S. election. Journal of Political Marketing, 16(3-4), 207-211. https://doi.org/10.1080/15377857.2017.1345828 